\title{
Beyond Hibernation: Ralph Ellison's 1982 Version of Invisible Man
}

\section{Steven Marx}

"What, if anything, is there that a novelist can say about his work that wouldn't be better left to the critics?" With this apparently selfeffacing disclaimer, Ralph Ellison begins his introduction to the "30th Anniversary Edition" of Invisible Man (v). Those familiar with his work may immediately suspect irony when they recall the many defenses and interpretations of the book Ellison has issued since its first appearance in the early ' 50 s. $^{1}$ In fact, Ellison starts out by playing a typical trick on the reader: The assumed answer to his rhetorical question is "nothing." But an equally possible answer is "everything": Whatever a critic could say would be better left to the novelist. Here, in the very act of striking a disjunctive contrast between novelist and critic, the writer identifies them with one another. ${ }^{2}$ This identification is borne out by Ellison's own career; since Invisible Man, he has published a distinguished body of criticism but no other novels. More importantly, the identification of novelist and critic shapes the Introduction itself. For in addition to providing a pertinent commentary on the original fiction, Ellison's later essay completes the novel's plot and becomes assimilated by it, making the 1982 edition a new work in its own right. ${ }^{3}$

This thesis summons an immediate objection, for it implies that Ralph Ellison, the named narrator of the Introduction, can be identified with the novel's anonymous narrator, usually referred to as Invisible Man. Such an identification appears to be denied by the divergence between some of the factual events of Ellison's and Invisible Man's lives-Ellison grew up in Oklahoma City, while

Steven Marx currently teaches English at California Polytechnic State University, San Luis Obispo. His publications include Youth Against Age: Generational Strife in Renaissance Poetry (1985). 
Invisible Man grew up in the deep South; Ellison was a musician before becoming a writer, whereas Invisible Man was a politicianand also by the author's explicit statement at the time of the novel's publication: "Let me say right now that my book is not an autobiographical work" (Shadow and Act 167).

However, just as the disjunction between critic and novelist must be qualified, so must this one between narrator and author. For although the two speakers are not identical, they may be identified. The voice of Invisible Man preaches the message and speaks with the accents of the voice we hear in the Introduction:

Could he have meant-hell, he must have meant the principle, that we were to affirm the principle on which the country was built and not the men, or at least not the men who did the violence. ... Not for the power or for vindication, but because we, with the given circumstance of our origin, could only thus find transcendence? (561)

Which suggested to me that a novel could be fashioned as a raft of hope, perception and entertainment that might help keep us afloat as we tried to negotiate the snags and whirlpools that mark our nation's vacillating course toward and away from the democratic ideal. (xvii)

These impassioned yet ironic declarations of allegiance to American ideals mark the utterance of a single speaker. Though Invisible Man's beginnings are not those of Ralph Ellison, in the course of the development charted by the novel, he comes more and more to resemble the person his creator became. Indeed, in a later comment Ellison qualified his own disclaimer: "The novel isn't autobiographical in an immediate sense" ("On Initiation Rites" 39 , emphasis added). It is the "non-immediate" sense in which Invisible Man is autobiographical that warrants the identification I imply. ${ }^{4}$ In what follows I shall adduce numerous further parallels that support such an identification. But the larger purpose of my essay is to explore the significance of these parallels, to display some as yet undisclosed aspects of the book's meaning that this identification reveals. In section 1, I will show how the Introduction concludes the earlier novel's open-ended story line and extends its foliated structure. In section 2 , I will show how intricate parallels between the Introduction's account of the writing of Invisible Man and the novel's account of Invisible Man's coming of age reinforce Ellison's aesthetic doctrine that the artist's process of creation resembles the individual's process of self-discovery.

The ending of the original edition of Invisible Man remains disturbingly unresolved, despite its apocalyptic finale in the riot, 
its retrospective coda in the coal cellar, and its valedictory postscript in the Epilogue. ${ }^{5}$ Though its hero/narrator claims to have learned his lesson and to better understand his relation to the world (561), he leaves the reader with a string of uncertainties and questions that exhibit more ignorance than knowledge. He doesn't know, he says, if the shape of life is "the way it had to be" or whether "accepting the lesson has placed me in the rear or in the avantgarde" (559). "I asked myself if it were only a joke and I couldn't answer" (565-66). He avers that "none of us seems to know who he is or where he's going"' (564). He is unsure about his own future: "What do I really want?"' (562); "What is the next phase?" (563). And his last sentence-"Who knows but that, on the lower frequencies, I speak for you?" (568)-with its double negative, its ambiguous qualification, its vague references, and its interrogatory form is as conclusive as a riddle wrapped in a mystery inside an enigma. In adding an Introduction that frames the novel with the perspective of hindsight, Ellison resolves the uncertainties by answering these questions.

As he reflects in the Epilogue upon the preceding twenty years, Invisible Man concludes that his past life has been a failure: "I have ... boomeranged a long way from the point in society toward which I originally aspired." Instead of fulfilling the expectations of becoming "a leader of his people," he discovers that he has been the butt of a "crude joke that had kept me running" (560). After divesting himself of the various false tokens that have given value to his life, all that he has left is the written account of his trials and delusions. This bit of autosalvage after his devastating collision with reality may help to release frustration and to record his hard-earned lessons, but he gives no indication that it could serve as more than a consolation prize. However, by the time his memoir surfaces in the later Introduction, it has taken on a pivotal importance. In the sequel we read of that Tale's emerging from underground and being composed and published as a book-a project that Invisible Man never mentions in the novel, but that in retrospect is seen to be the logical next step in his development. The Introduction itself concludes with triumphant references to that book's continuing public success and testifies to the consequent redemption of its author:

My highest hope for the novel was that it would sell enough copies to prevent my publishers from losing on their investment and my editor from having wasted his time. But, as I said in the beginning, this has always been a most willful, most self-generating novel, and the proof of that statement is witnessed by the fact that here, thirty astounding years later, it has me writing about it again. (xix-xx) 
The Introduction answers the questions "What do I want?" and "What is the next phase?" by presenting a narrator who has become a professional writer. As opposed to a politician's or a propagandist's, it is a writer's job to express personal opinions and individual perceptions. This social role could surely fit Invisible Man's particular character traits: his obsessive subjectivity, his intellectuality, his bookishness, eloquence, and wit. Ellison knew the odds against a black man's attaining such a position in America; the likelihood is greater that he would end up like one of the inmates of the Golden Day-black professionals who went mad from not being able to find a place for their talents. But though uncertain, at the end of the Epilogue, Invisible Man is ready to take the risk of aspiring to this profession. To take that risk elucidates what Invisible Man means when he announces his mysterious resolve to "come out of hibernation." For if he is successful, the writer emerges from hiding and moves into the spotlight, even if he never grants a single interview. Publishing an autobiographical novel draws attention to oneself and appropriates a public identity that can live on in fame, even beyond the individual's death. The Introduction becomes proof that the risk was not futile. Only a very successful book merits a critique by its own author.

Invisible Man's decision to give up public life in order to reflect upon himself involves another kind of risk: that he will be tormented by the claims of his social conscience. Does dedicating himself to the career of writer and introspective thinker-an invisible, as opposed to a public, man-permanently or necessarily involve cutting himself off from his fellow human beings and from the historical process of collective struggle for full humanity?' The Brotherhood would say yes, and Invisible Man ironically concedes his failure on this account, using their characteristic jargon: "Nor do I know whether accepting the lesson has placed me in the rear or in the avant-garde. That, perhaps, is a lesson for history, and I'll leave such decisions to Jack and his ilk ..." (559). But his language here is sly as well as prophetic. The lesson actually taught by history is that the book has placed him in the avant-garde, both politically and culturally, has confirmed the "possibility that even an invisible man has a socially responsible role to play" (568). As a classic of modern American literature, widely studied in schools and universities, it has raised black consciousness and generated support for black political claims among whites. As a contribution to the heritage of Afro-American culture, specifically the traditional tale of liberation and empowerment through the power of the pen, it has enriched black intellectual/artistic pride and stimulated the 
growth of Afro-American scholarship. ${ }^{7}$ In the Introduction, Ellison carries the wordplay one step further with a coy allusion to the book's luminary career: "The rest, as the saying goes, is history" (xix). ${ }^{8}$

The most profound question of the Epilogue is whether or not the disillusioning course of Invisible Man's life was "the way it had to be" (559). A negative answer implies the absurdity of the world, whereas a positive one implies the existence of some higher agency or design-"a divinity that shapes our ends." The issue of destiny or fate raised by this question crops up throughout the novel, for example in a series of allusions to Sophocles' Oedipus the King and in explicit exchanges between Invisible Man and Mr. Norton in the second chapter and in the Epilogue. ${ }^{9}$ In seeking "to study the lesson of my own life," Invisible Man searches for the design of destiny in order to imbue his tribulations and those of his race with purpose. To find such a design could enable him to emerge from his underground retreat and would link such a return to the world with the rebirth of an archetypal mythic hero.

In a typical heroic narrative, the protagonist discovers his destiny during a trip underground to a place beyond time whose inhabitants give him information about the future that enables him to come to terms with his past and take heart in the present. It is to make this discovery that a demoralized Aeneas, directed by the Sybil, visits his father in Hades in the sixth book of the Aeneid. Likewise, Invisible Man's trip underground gives him "a slightly different sense of time .... Instead of the swift and imperceptible flowing of time, you are aware of its nodes, those points where time stands still or from which it leaps ahead. And you slip into the breaks and look around" (8). Led there by another ugly and intoxicated woman named Sybil, passing through the hellish scenes of the Harlem riot and dreams of murder and castration, he finally receives his grandfather's message. But within the novel, that message remains tentative and ambiguous. Unlike Vergil, who could set the revelation of Aeneas's future in the past, the narrator and author of the original version of Invisible Man did not yet know what was to come. It was only from hindsight that his fate could be revealed, that he could be shown actually to emerge.

If, as I have argued, the Introduction provides a crucial sequel to the novel, the question remains: Why is it placed as a preface rather than a postscript. One can adduce a number of reasons, some general, some specific to the work. Like many twentieth-century writers, the author of Invisible Man is interested in experiences that expand our concepts of time and duration-in showing that "the 
end was in the beginning" (558). Some of those experiences are purely subjective, due to the influence of violence or drugs; others are cultural, due to the discrepancy between tribal time and punchclock time; still others are literary, due to the ability of remembering, writing, and reading to alter the rate and direction of time's flow.

Ellison alludes to this particular power of literature in the second sentence of the Introduction, when he compares the experience of writing about the 1952 novel in 1981 "to that of commanding a smoky genie to make an orderly retreat ... into the ribbon and keys of a by now defunct typewriter"'(v). He brings off this feat of magic in the reminiscence that follows. The moment at which he remembers and adds to the book is an Archimedean point outside of time. We see him, perhaps more like Dante than Vergil, contemplating the book that contains between its covers the flowing passage of his life "bound up into a single volume, all of the leaves scattered through the universe" (Paradise 33:85-87).

Putting the character of the narrator and the events he relates in such a perspective insulates readers from some of the shocks of the earlier edition of the book and evokes their sympathy rather than their distrust at the start. One may speculate that Ellison has chosen this approach not only as a result of his own mellowing with age and success, but also in order to attract new readers of the present generation who are not eager for stark confrontation. In drawing attention to the status the work has achieved, the Introduction also appeals to the book's old friends, whose rereading will be freshened by the novel's new configuration.

The power of hindsight to extend one's perception of a given experience suggests another way in which the Introduction completes the novel. In addition to supplying the ending to a cliffhanging tale, it completes the major formal, non-chronological pattern of the work. This is the pattern of multiple framing perspectives that enclose Invisible Man's Tale and the tales within it in a layered nest of commentaries.

In the original novel, the Prologue introduces the voice of a character who is about to narrate the story of his past life-a story that leads up to and accounts for his self-confident but violent and bewildered present. The Epilogue depicts the same character commenting on the process of the narration and depicting the ways the writing of the story has pacified him and clarified some of his bewilderment. The new Introduction extends this structure of three layers with a fourth: the voice of the author recalling the process of the novel's composition thirty years earlier and dramatizing how, in the interim period, its publication and acceptance have resolved 
what confusion and uncertainty remained for the narrator of the Epilogue.

Just as it adds a happy ending to the story line, so in this formal framework the Introduction completes an optimistic progression running counter to the Tale's pessimistic descent. For it suggests that with the disillusion of experience comes a self-created extension of the field of vision upon which the mind can assimilate contradictions into patterns of greater complexity and richness. Ellison displays this progression through changes in the narrative persona's character and in his relation to the reader as each successive layer unfolds.

The "I" of the innermost layer, Invisible Man's Tale, is an eager Candide-like hero convinced that "the world was solid and all the relationships therein" (563). His associations with those he encounters are simple and dependent, and therefore he is continually gulled-by the school superintendent, Bledsoe, Norton, and Jack. He has neither personal authority nor consistency, always representing others who define his roles and goals and shifting his opinions with the vicissitudes of circumstance. The reader is repeatedly made aware of the protagonist's folly and is privileged to understand him better than he does himself. In short, Invisible Man's protagonist is the typical adolescent hero of the educational novel on a quest for personal identity.

The narrator of the Prologue has completed this quest. No longer naïve, he has seen through the deceptions and hypocrisy of the world and arrived at the discovery that "I am nobody but myself" (15). He expresses this radical individualism by refusing to abase himself before the representatives of white authority, by stealing from the power company, and by nearly murdering a Big Blond Man. His way of life-isolated, underground, solipsistic-combines the inwardness of dreams and drugs with the aggression of con games and mugging. His tone of voice is that of an angry black confronting a white in an anonymous street encounter, by turns lyrical and threatening, charming and hostile, oracular and wily. $\mathrm{He}$ ingratiates, repulses, and disorients the white reader, who experiences a lack of understanding not only of the narrator's behavior, but also of his black dialect, arcane wit, and private references. ${ }^{10}$

The " $\mathrm{I}$ " of the Epilogue retains the insight and self-confidence of the Prologue's, but writing down and studying his experience has "negated some of the anger and some of the bitterness" (566) and has made him decide to resurface in search of a socially responsible role. Instead of speaking as an outlaw individual, he 
takes it upon himself to represent "the Negro." Instead of mugging the man who has actually harmed him, he only taunts old Mr. Norton in the subway. Though he finds it "a feat of the utmost difficulty," he says he will be honest with the reader. This comparatively reliable narrator still retains some anger and bitterness, however, and is "confused" as to what his role can be. Though conciliatory and eager to reach out, he approaches the reader and the world in general with a degree of testiness and evasion: "I sell you no phony forgiveness, I'm a desperate man-but too much of your life will be lost, its meaning lost, unless you approach it as much through love as through hate" (566-67).

Not until the Introduction does the "I" who addresses the reader of this book sound fully comfortable, pacified by the broad perspective of later vision. His voice is genial and authoritative; his words are rich with hidden meanings, but not evasive or ambiguous. In an incident that corresponds to the mugging in the Prologue and the encounter with Norton in the Epilogue, Ellison is treated like an invisible man by a black woman, but he responds to her challenge only with detached irony. He speaks no longer as a disenfranchised black, but as an eminent fellow American. His subject is no longer the personal or group ordeal that distinguishes him from the reader, but rather the "most self-willed book" that they regard in common.

So far I have suggested ways in which the critic who wrote the Introduction to Invisible Man functions as a novelist by making the 1981 essay a concluding sequel to his earlier story. In the same Introduction, the novelist functions as a critic by recounting a vivid and amusing tale whose underlying structure mirrors and thereby elucidates the novel he is writing about.

Ellison offers the Introduction as the story of the seven-year genesis of Invisible Man, an account of his search for satisfactory artistic utterance. In it, he characterizes the creative struggle required to produce the book as a series of "blundering step[s] toward the present novel" (ix). The image of blundering steps, with its evocation of the painful but comic attempts of a toddler learning to walk, also suggests the bumbling efforts of an adolescent aspiring toward psychological and spiritual self-locomotion. This image of awkwardness, absurdity, and indefatigable determination is an apt description of the narrator's career in Invisible Man. It is therefore probably no accident that, later in the Introduction, Ellison reverts 
to the same image when he refers to his hero's life story as a "blundering quest for freedom" (xviii). The "blundering step[s]" of the Introduction not only continue the "blundering quest" of the novel itself, but analogize them. That the story of the novel's genesis recapitulates the overall action of the book confirms an implication which Ellison has elsewhere stated explicitly: For the artist, the achievement of aesthetic form is identical with the epiphany of self and its relation to the world. ${ }^{11}$

The Introduction's account of the composition of Invisible Man is divided into three major parts by the author's summarizing or prefatory transitions. ${ }^{12}$ The first section elaborates the setting and the conditions of the novel's composition and concludes on page ix: "So much then for the economics, geography and sociology of the struggle sustained in writing the novel, and back to the circumstances in which it began." The second section moves back in time and depicts the conflicts and false starts that led up to the actual writing of the novel. It ends on page xv: ". . . with that $I$ began to structure the movement of my plot, while he [the disembodied voice of his mischievous muse] began to merge with my more specialized concerns ...." The third section, which carries on from here to the end, consists of a reflection upon the author's final purposes and methods for writing the book. The parts of the Introduction divided by these signposts match the novel's sections of Prologue, Tale, and Epilogue.

The first part of the Introduction ( $\mathrm{v}$-ix) portrays the writer in a number of liminal, garret-like situations. He is on retreat from the normal "economics, geography and sociology" of the surrounding society, enjoying the protection of his sanctuary, but also enduring isolation and self-consciousness. Just as Invisible Man resides in an area marginal both to black and white society - "I don't live in Harlem but a border area" (5)-so Ellison recounts his "bouncing back and forth" between St. Nicholas and Fifth Avenues. Just as Invisible Man works away in a basement, Ellison produces his manuscript "at the highest elevation" of the eighth floor. Just as Invisible Man is nourished and inspired by the light bulbs that illuminate his "warm hole," Ellison's ego is buttressed by the flow of "pearls and diamonds, platinum and gold" through the suite where he squats at the sufferance of absentee tenants.

Invisibility is an essential characteristic of both narrators. Invisible Man walks softly so as not to awaken the sleeping ones, while Ellison moves unperceived through the city, hidden by his "indefinite status" and his lack of a social role. Such alienation exacts public humiliation: for Invisible Man being roughly bumped 
and denied the courtesy of an apology on the street, for Ellison being loudly labeled as a "sweetback" or pimp by the "wino lady" as he walks through his own neighborhood. Invisibility also induces a private malaise: Invisible Man's "ache with the need to convince yourself that you do exist in the real world" (4) and Ellison's "shaky self-confidence" and his fear of being told to use the service elevator (vi). Both speakers, however, assert the far greater advantages that their invisibility has taught them to reap. They have learned to elude the culturally defined limitations of a proper station. By being in both figurative and literal senses "off-beat," each manages to "slip into the breaks" and step "inside of his opponent's sense of time," thereby overcoming the odds and making "the smart money hit the canvas" (8). Without paying the usual price, Invisible Man gets just what he needs, free rent and electricity, while Ellison gets a free office and time to write, supported by temporary jobs, rich white patrons, and his gainfully employed wife.

There is a manic hilarity to both of their expressions of personal triumph over a system that oppresses all creative individuals and that makes self-definition and artistic expression particularly difficult for blacks. But that glorying tone is uncertain and unstable. Invisible Man oscillates abruptly between effusions of arrogance and paroxysms of guilt, between ingratiating himself with and assaulting the reader, while the speaker of the Introduction mixes indignation against race and class oppression with adulatory tributes to his white benefactors. In both cases, as readers we fear being yessed to death and destruction, being betrayed by a voice like Grandfather's, whose loyalties to himself and to us remain mysterious and confused. This dissonance remains pending like an unresolved chord until the final section of each piece.

The Prologue to Invisible Man ends with a question and an invitation: "But what did I do to be so blue? Bear with me" (14). The second section of the work-the "Tale," or novel properconsequently takes the form of an etiological flashback, a narrative of the causes of the present situation that begins twenty years before and ends at the time of the Tale's narration. Similarly, the second section of the Introduction, extending from page ix to $\mathrm{xv}$, moves back in time to the period preceding the writing process and chronicles the struggles within the author's mind that end with the genesis of the novel. Just as Invisible Man experiences the events of his previous life as a series of increasingly violent incidentsincidents modeled upon the opening scene of the "Battle Royal" and fulfilling his grandfather's prophecy that "our life is a war"-, so in this section of the Introduction Ellison's conception of the 
incipient novel and the process of its creation centers on the idea of martial violence: "Despite its peacetime scenery it erupted out of what had been conceived as a war novel" (v).

The original plan for this projected work, the author tells us, was stimulated by his reading of the war novels of Hemingway and Malraux. His purpose, along with that of the two previously published short stories he summarizes, was to depict "the war within the war" fought by black American soldiers. A result of "the prevailing mystique of race and color" (x), that war subjects black Yanks to the "existential torture" of frustrated idealism and confused loyalties, for though they are willing to serve their country with their lives, they are hated more by their fellow Americans than by their foreign enemies. The racial mystique also confounds their private search for personal identity, a theme he had explored in a previously published story of an Air Force pilot who "crash-landed on a Southern plantation" and was helped by a tenant farmer "whose outlook and folkways were a painful reminder of his own tenuous military status and their common origin in slavery." Like the "bouncing" writer and the "boomeranging" Invisible Man, all these warriors are dislocated by cultural contradictions: They are men "of two worlds, ... misperceived in both" (xi). ${ }^{13}$

Invisible Man's Tale of escalating war between the individual and society eventually ends with disarmament and peacemaking. A similar passage through war to peace orders the second section of the Introduction. Given "the unavailability of legal protection" from the "ritual sacrifice" (xii) of lynchings and burnings inflicted on blacks, the writer becomes convinced that violent resistance is of no use. Rather than producing "another novel of racial protest," he aspires to create "a dramatic study in comparative humanity" (xv). Rather than expressing "raw anger" (xiii) at the predicament of his black heroes, he finds the only support for their will to endure-the only "subtle triumph" (xii) possible-in "blues-toned laughter" (xv). Reporting this transformation of his projected book from a war novel to a story of disarmament, Ellison employs an arresting simile: "I was most annoyed to have my efforts interrupted by an ironic, down-home voice that struck me as being as irreverent as a honky-tonk trumpet blasting through a performance, say, of Britten's War Requiem" (xii). That trumpet is perhaps identifiable as the very "military instrument" that, in the novel, Louis Armstrong "bends . . . into a beam of lyrical sound" (8).

As the military setting is abandoned in this section of the Introduction, the "war within the war" continues in another theater of operations. It becomes a battle between two modes of literary 
composition, two approaches to creation competing within the author's mind: "Perhaps . . . war could, with art, be transformed into something deeper and more meaningful than its surface violence" (xiv). The two opposing sides are Ellison's conscious mind, with its preconceived plan of writing a war novel, and the disembodied voice of the future Invisible Man, which "issued from ... underground" (xiv). For a long time, Ellison reports, the rational and purposeful writer resisted this subversive voice: "I was still inclined to close my ears and get on with my interrupted novel" (xiv). But he was eventually overwhelmed by its superior force-"its pied rind and surreal heart" (xiv). Once again hinting at the formal analogy between novel and Introduction, Ellison here alludes to the name of his fictional shape-shifting con man Rinehart to characterize the protean energy of pure imagination that wars with the preconceived ideas or absolute morality of traditional art.

The invisible voice awakens his mind to what Ellison calls a state of "hyperreceptivity," a kind of Keatsian negative capability that confers aesthetic value on every "idea-emotion" that passes through his consciousness. The province of Modernist artistic creation is new territory for him, and he finds it threatening. "Like many writers atoss in what Conrad described as the 'destructive element' " (xiv$\mathrm{xv})$, he fears the dangers of that unconscious place in which contradiction thrives, in which there is no demarcation between truth and untruth, in which value judgments are dissipated by pure relativity, in which existence precedes essence.

But though the hyperreceptive writer risks drowning "in the quicksands of indecision," only he is eligible to receive "unexpected gifts from his daydreaming muse" and to gain access to his own deepest capacities. Once Ellison surrenders his previous position-first, by no longer closing his ears to that voice, second, by listening "to its taunting laughter," and, finally, by "coaxing [its speaker] into revealing a bit more about himself"-, the author takes control of the artistic process from the disembodied voice and appropriates it as his own: ". . . with that $I$ began to structure the movement of my plot, while he began to merge with my more specialized concerns ..." (xv).

By representing his composition of the novel as a passage from war to peace, Ellison draws revealing parallels to Invisible Man's self-discovery as a passage from alienation to social adjustment. At first, while Invisible Man adheres to the rigid scripts and preconceived ideals of others who are either "for" or "against" society, he remains embroiled in a "war within the war"; like his grandfather, he finds himself " "a traitor all my born days, a spy in 
the enemy's country" "(16). Then, in cutting loose and casting himself afloat in the "destructive element"-during the riot as Rinehart and as Jack the Bear in hibernation-, he accepts the chaos of society and the darkness of his own nature, rapidly shifting his perspectives and losing his bearings amid a perplexing cacophony of memories, dreams, and symbolic epiphanies. Finally, after writing out his experiences, he finds an integrated identity and a willingness to make his own, as yet unspecified, place in the world: "So now having tried to put it down I have disarmed myself in the process" (567).

These chronological parallels between the conception of the novel in the second section of the Introduction and the progress of Invisible Man's career are distinct from the larger formal parallels between the sequence of Prologue, Tale, and Epilogue and the three sections of the Introduction as a whole. It is in analogies between the third section of the Introduction and the Epilogue that Ellison's structural mirroring is most clearly evident and most useful for deciphering dense and problematic passages.

Coming to terms with the disembodied voice in the Introduction is analogous to Invisible Man's making peace with the voice of his grandfather. Up until the Epilogue, that voice has been a mocking and disruptive influence. But once he has reached a clear sense of himself in isolation, the narrator appropriates that voice as his own, and it strengthens his purpose instead of undermining it.

In both the Introduction and the Epilogue, that purpose is identified with the search for a role of "social responsibility" (xvi, 568). Ellison uses this term to denote overcoming the alienation (or "war") between the black individual and a white society. One aspect of this war is the rift between the high ideals held by a young person searching for identity and the covert realities of a racist social structure. Though it is essential for the artist to teach people to confront these realities and strip "away . . illusionment" (546), making peace between the individual and society requires the reaffirmation of ideals as inspiration and guides. Just as a loss of faith in given social meanings and values is a necessary stage of conscious and cultural development, so "the next stage" anticipated by Invisible Man in the Epilogue consists of a qualified reacceptance. Invisible Man makes such a leap of faith by reversing his grandfather's sarcastic " 'Agree 'em to death and destruction" " (562) into an affirmation that "the principle on which the country was built and not the men ... the principle was greater than the men, greater than the numbers and the vicious power and all the methods used to corrupt its name"' (561). 
Such an illogical reversal from the depths of disillusion to a "higher innocence" constitutes the "thrust toward an ideal" which, in the Introduction, Ellison asserts as the only alternative to despair. Rejecting the social pessimism of Richard Wright and the metaphysical pessimism of many Modernists, he affirms the traditional humanist's demand that art teach as well as delight by creating believable visions of the way things should be. ${ }^{14}$ His example is the vision of racial harmony between Huck and Jim on the raft in Huckleberry Finn. Creating such a "raft of hope" translates the writer's social responsibility into a politics that is not revolutionary but Utopian: "negating the world of things as given in favor of a complex of manmade positives" (xvii).

However, both Ellison and Invisible Man admit that this leap of faith is not merited by the evidence either of personal experience or of black history, with their recurrent cycles of hopes raised and then dashed. In fact, this late-won idealistic attitude disturbingly echoes the naiveté or futility of the experiences recounted at the beginning of the Tale and in the opening of the Introduction. "Social responsibility" is precisely what the white bigots demanded from the eager high school graduate at the Battle Royal, and the soldier of Ellison's ur-novel "had either to affirm the transcendent ideals of democracy and his own dignity by aiding those who despised him, or accept his situation as hopelessly devoid of meaning; a choice tantamount to rejecting his own humanity" (ix).

As his argument thus approaches the circular in both Introduction and Epilogue, the writer recognizes the fallacy and is forced to qualify his affirmation of the "transcendent truths" of a "fictional vision of an ideal democracy" (xvii) to deal with the contradiction. He again invokes Huckleberry Finn, no longer as a raft of hope, but "as a comic antidote to the ailments of politics." The emphasis on social responsibility is redefined by a new imperative. The writer's purpose is not so much to ameliorate or make sense out of human fate, but to recognize, clarify, and assert its unfathomable contradictions. His task becomes one of presenting heroes who are "allowed to snatch the victory of conscious perception from the forces that overwhelmed them" (xviii, emphasis added).

The meaning of the particular form of peacemaking denoted by this expression is not easily specified. It is perhaps the kind of recognition that draws together Achilles and Priam at the end of the Iliad, the wisdom through suffering accorded to Oedipus, the vision expressed by Louis Armstrong in "What did I do / To be so black / And blue?" (12). In the Introduction, Ellison attributes "the victory of conscious perception" to "Brer Rabbit and his more 
literary cousins, the great heroes of tragedy and comedy" (xviii), whereas, in the corresponding place in the Epilogue, the narrator struggles to define this value by its absence in the parable of his last meeting with Mr. Norton.

The distinguished Boston millionaire and trustee of Bledsoe's college, who has earlier been characterized as a "bearer of the white man's burden . . . a symbol of the Great Traditions" (37), has lost his way on the subway looking for "Centre Street." But he is too proud to display his disorientation to whites and therefore approaches an anonymous black man for guidance, assuming, according to Invisible Man, that blacks have "learned to live without direction" (564). The narrator recognizes him immediately and rebukes him for the betrayal he has perpetrated, but the old man has no idea what Invisible Man is talking about and jumps on the next train without knowing where it is going, simply to avoid the confrontation.

This encounter recapitulates an earlier one in which Invisible Man drove Norton around the countryside and the trustee confessed both that he asked direction from the black founder of the college and that his ancestors "didn't know in what direction they should turn" after the Civil War (38-39). Despite this ignorance, Norton played the role of "A Trustee of Consciousness" and, like the deluded Oedipus at the beginning of Sophocles' play, complacently bragged about his "pleasant fate." His blind hubristic claim to understand and control highlights, by contrast, the meaning of Ellison's "victory of conscious perception."15 Norton's blissful delusion is diametrically opposed to the tragicomic consciousness of Trueblood, the incest-committing sharecropper who fascinates and terrifies the trustee and who, like Oedipus after his revelation, has learned to live without direction and yet has found his center: "' 'I thinks and thinks, until I thinks my brain go'n bust, 'bout how I'm guilty and how I ain't guilty. . . . I makes up my mind that I ain't nobody but myself and ain't nothin' I can do but let whatever is gonna happen, happen' "' (65-66).

Trueblood's true consciousness is of the ambivalence at the heart of his destiny. Illuminations of such consciousness recur at crucial moments in the novel and are accorded an oracular authority, as for instance in this fragment of the reefer dream in the Prologue:

"I dearly loved my master, son," she said.

"You should have hated him," I said.

" . . because I loved my sons I learned to love their father though I hated him too." 
"I too have become acquainted with ambivalence," I said. "That's why I'm here." (10)

Ellison sees such "acquaintance with ambivalence" as particularly intense in Afro-Americans, whose heritage of slavery has destined them to continue living out the core contradiction dramatized in this fragment. The same irreducible ambivalence plagues the black soldier aiding those who despise him, and the grandfather, who, despite laying down his gun, warns his grandson of their ongoing war with society. To grasp his mysterious prophecy fully, Invisible Man must come to understand that, like the anonymous slave woman, his grandfather both hates and loves, means "yes" both sarcastically and literally. ${ }^{16}$

The consciousness of ambivalence is a blessing as well as a curse. As with Trueblood and Invisible Man, it allows finally for the discovery and acceptance of a unique and authentic self, a self whose being resides in its freedom to act beyond the "overwhelming forces" of circumstance. This freedom is also defined in the dream sequence of the Prologue:

“. . what is this freedom you love so well?". . .

"I done forgot, son. It's all mixed up. First I think it's one thing, then I think it's another. It gits my head to spinning. I guess now it ain't nothing but knowing how to say what I got up in my head. But it's a hard job, son." (11)

The heroic burden of such freedom demands and depends on utterance: the conscious expression of ambivalence. After his dark night of the soul, Trueblood sings himself into existence with "some blues that . . . ain't never been sang before" (65-66), just as Louis Armstrong blows good music out of "Bad Air." And so, at the same point in the structure of the Epilogue and the Introduction, the speaker moves from defining the notion of heroic consciousness to proclaiming its victory as the very process of writing:

So why do I write, torturing myself to put it down? Because in spite of myself I've leamed some things. ... . So it is that now I denounce and defend .... I condemn and affirm, say no and say yes, say yes and say no.... So I approach it through division. So I denounce and I defend and I hate and I love. (566-67)

Therefore I would have to create a narrator who could think as well as act, and I saw a capacity for conscious self-assertion as basic to his blundering quest for freedom. (xviii)

Here, at the end of the quest, a number of themes that have run parallel between novel and Introduction finally converge. The ultimate stage in the evolution from war to peace between individual 
and society is achieved through a commitment to express and teach the consciousness of ambivalence. The fulfillment of social responsibility comes not in an idealistic peroration but in an honest admission of both love and hate toward the reader: "You'll fail to see how any principle that applies to you could apply to me. You'll fail to see it even though death waits for both of us if you don't" (567). This vision acknowledges that the prospect for peace between blacks and whites is poor, and yet such a peace can be purposefully pursued through art: "My task was . . . to defeat this national tendency to deny the common humanity shared by my character and those who might happen to read of his experience" (xviii). Thus, the conclusion of Invisible Man's quest coincides with the crystallization of Invisible Man's concept. The fictional character's discovery of himself as an aspiring writer signals his metamorphosis into the nonfictional character of Ellison the author. For the reader, the synchronic, analogical relationship between Introduction and novel intersects with the diachronic, sequential relationship, and the two parts of the work-written at a thirty-year interval-blend into a single whole.

\section{3}

If ambivalent consciousness is the only attainable truth of self and of art, it makes sense that the writer's language should embody that ambivalence not only in its contradictory assertions but in a witty style that celebrates its freedom from consistency in spontaneous play. Invisible Man's last few paragraphs do just this, with a dense and breathless flow of associative leaps, unexpected tone shifts, hidden allusions, suggestive symbols, and ingenious wordplayat once gratifying readers with its ability " "to say what I got up in my head" " (11) and teasing them with a game of hide-and-seek for direction and meaning. The jazz-riff-like performance suddenly breaks off with the narrator's direct address: “ 'Ah,' I can hear you say, 'so it was all a build-up to bore us with his buggy jiving. He only wanted us to listen to him rave!' But only partially true"' (568). This "disarming" recognition by the speaker also disarms us, for it anticipates and helps lessen the likelihood of the reader's offering a naïvely negative response. It attracts and repels in a heightening frequency of oscillation that links his mixed feelings to our own.

The Introduction, as I mentioned earlier, ends with the same kind of move, in which the writer steps from behind the page and joins the reader in reflecting upon the book before them. At the opening of its final passage, Ellison again affirms the ambivalence of the 
novelist, who reaches truth through telling lies and achieves seriousness through play. As in the Epilogue, though here with greater restraint and clarity, he enacts these concepts in the performance of his style:

It would be misleading, however, to leave the impression that all of the process of writing was so solemn. For in fact there was a great deal of fun along the way. I knew that I was composing a work of fiction, a work of literary art and one that would allow me to take advantage of the novel's capacity for telling the truth while actually telling a "lie," which is the AfroAmerican folk term for an improvised story. Having worked in barbershops where that form of oral art flourished, I knew that I could draw upon the rich culture of the folk tale as well as that of the novel, and that being uncertain of my skill I would have to improvise upon my materials in the manner of a jazz musician putting a musical theme through a wild star-burst of metamorphosis. By the time I realized that the words of the Prologue contained the germ of the ending as well as that of the beginning, I was free to enjoy the surprises of incident and character as they popped into view. (xviii-xix)

While commenting upon themselves, these sentences conceal in their form variations of the dialectical pattern that shapes the whole book. They align a parallel series of polar tensions-solemnity vs. fun, truth vs. lies, the literary culture of the novel vs. the oral culture of the folktale, uncertain composition vs. spontaneous improvisation-and thereby generate a voltage that finally explodes in a pyrotechnic release of creative energy: "a jazz musician putting a musical theme through a wild star-burst of metamorphosis." Recreating the writer's experience of struggle and breakthrough, Ellison's prose momentarily resolves the antinomies of white-black, critic-novelist, reader-author and frees us all to enjoy what pops into view.

\section{Notes}

'Two of Ellison's critical explications of Invisible Man are cited below. His observations, like those about structure and symbol from "The Art of Fiction," provide a model for my own critical efforts:

The three parts [of the novel] represent the narrator's movement from, using Kenneth Burke's terms, purpose to passion to perception. These three major sections are built up of smaller units of three which mark the course of the action and which depend for their development upon what I hoped was a consistent and developing motivation. . . Each section begins with a sheet of paper; each piece of paper is exchanged for another and contains a definition of his identity, or the social role he is to play as defined for him by others. ... Once he recognizes the hole of darkness into which these papers put him, he has to burn them. (Shadow 176-77)

"The trick can be classified as "signifying," a rhetorical strategy that Henry Louis Gates, Jr., calls the "master trope" of Afro-American literature $(286,288)$. Roger Abrahams defines signifying as "the monkey's ability to talk with great 
innuendo, to carp, cajole, needle and lie. . . the propensity to talk around a subject, never quite coming to the point" (54). According to Gates "Ellison, of course, is our Great Signifier, naming things by indirection and troping throughout his works" (292).

${ }^{3}$ To my knowledge, no discussion of the Introduction in the 1982 edition has yet appeared in print. This study therefore focuses on a close reading of the text in its relationship to the earlier novel it comments upon. But some considerations of influence are necessarily relevant. In particular, Ellison's Introduction is modeled upon "How 'Bigger' Was Born," Richard Wright's autobiographical essay about the composition of Native Son. Like Wright, Ellison supplies a conventional Afro-American framing apparatus to authenticate his narrative. Like Wright, who is "going to try to account for as much of [Native Son] as [he] can, the sources of it, the material that went into it, and [his] own years' long changing attitude toward that material" (vii), Ellison undertakes "the task of accounting for the process involved in putting ['the words on the page']" (v). For both, such an accounting for the book is an accounting for the author's life, at once pressing and impossible to accomplish fully. Both introductions describe the circumstances leading to the novels' conceptions, the conditions under which they were completed, the struggle by which inner obstacles to the writing process were overcome. Both pay tribute to white literary mentors and conclude with restatements of their reflections on the oppression of blacks in the final pages of the novels.

However, these imitative similarities are offset by equally important differences. Whereas Wright attributes the "material" of Native Son to an account of his own real-world experiences of growing up black in white America, Ellison depicts the sources of Invisible Man as a combination of his own and others' fictions. And whereas Wright tells us how he wrought Bigger Thomas with a preordained purpose-to embody eight specific "levels of life" when he "had yet to put him into an image" (xxiii)-, Ellison tells us how he relinquished his own plans to write a novel of social protest to the insistent demands of a character emerging through his unconscious. These contrasts of substance are reflected formally and stylistically. Though published the same year as the novel, Wright's essay appeared as a magazine article and was only bound with the novel in some later editions. Except in a few passages, its tone is that of the pure critic-factual, didactic, and authoritative. On the other hand, although Ellison's Introduction comes thirty years after the novel, its mercurial tone and dense imagery blur the border between criticism and imaginative literature. His whimsical account of the novel's genesis is itself plotted like a fiction around the conceit that the book was "self-willed and self-generating." And rather than the self-congratulatory stance of Wright or the urgent selfquestioning stance of Invisible Man's narrator, the 1981 narrator adopts a posture of self-effacing but confident irony. In this sense, he "signifies on" both "How 'Bigger' was Born" and Invisible Man itself. As Gates observes: "Afro-American literary history is characterized by such tertiary formal revision, by which I mean its authors seem to revise at least two antecedent texts, often taken from different generations or periods within the tradition. . . . It is clear that black writers read and critique other black texts as an act of rhetorical self-definition. Our literary tradition exists because of these precisely chartable formal literary relationships, relationships of signifying" (290).

"Ellison's hedging on the question of autobiographical veracity anticipates contemporary controversy about the definition of the genre. On one side stand Phillip Le Jeune and others, who argue that autobiography is absolutely distinct 
from fiction or imaginative literature because of its commitment to factuality. Author's intention and reader's expectation are determined by an "autobiographical pact," ensuring that the events narrated in the text refer to events that actually took place in the past. See Le Pact Autobiographique (Paris: Seuil, 1975) 13-45. This claim is challenged by Eakin: "I shall argue that autobiographical truth is not a fixed but an evolving content in an intricate process of self-discovery and self-creation, and, further, that the self that is the center of all autobiographical narrative is necessarily a fictive structure.... Autobiography in our time is increasingly understood as both an art of memory and an act of the imagination; indeed, memory and imagination become so intimately complementary in the autobiographical act that it is usually impossible for autobiographers and their readers to distinguish between them in practice" $(3,5-6)$. See also Bruss and Olney. For a full discussion of the relationships between autobiography and fiction in the earlier edition of Invisible Man, see Vauthier.

5The ambiguity of the novel's ending is evidenced in the range of interpretations and judgments it has been subject to. For a recent review of the literature on this topic, see Winther 268-71.

${ }^{6}$ Ever since the publication of Invisible Man, Ellison has been under attack by a variety of critics for refusing to commit his work as a writer to black political struggles. See Howe and Blake.

${ }^{7}$ See Stepto for a study of the conventional use of prologues and epilogues as an author's way of authenticating a narrative and appropriating the meaning of his or her own life's experience in Afro-American literature.

'Ellison's ideas about "history" are the subject of Callahan. Clearly Ellison rejects the historical materialism of the Brotherhood, whose faith in progress consigns the aged Provos and black traditions in general to "the dustbin of history."

'See the paragraph surrounding note 15.

${ }^{10}$ The issue of the identity of the reader addressed by Invisible Man is vexed:

Characteristically, in the Prologue, only on two occasions does the narrator evoke briefly an inclusive we-group.... In the Epilogue, on the contrary, he refers at length and repeatedly to two we-groups: the Black minority which is seen as a component part of the national community ("Weren't we part of them as well as apart from them and subject to die when they died?" ... ), and the collective American We of the Epilogue, thus not directly addressed, is the audience toward which he orients his writings as well as his message. (Vauthier 81)

${ }^{11}$ For example, in "Hidden Name and Complex Fate":

I made a most perplexing discovery; namely, that for all his conscious concern with technique, a writer did not so much create the novel as he was created by the novel. ... And the process of acquiring technique is a process of modifying one's responses, of learning to see and feel, to hear and observe, to evoke and evaluate the images of memory and of summoning up and directing the imagination; of leaming to conceive of human values in the ways which have been established by the great writers who have developed and extended the art. And perhaps the writer's greatest freedom, as artist, lies precisely in his possession of technique; for it is.through technique that he comes to possess and express the meaning of his life. (Shadow 162-63)

${ }^{12}$ Such nods to the reader recall Ellison's critical analysis of the novel cited above and also Invisible Man's suggestions on how to parse his own Tale: "I started out with my share of optimism . . . , but now, after first being 'for' society and then 'against' it, I assign myself no rank or any limit ..."' (563).

${ }^{13}$ For additional discussion of Ellison's use of the metaphor of war, see Callahan 38, 47-48. 


\begin{abstract}
${ }^{14}$ Houston Baker points out the relevance to the traditions of Afro-American literature of this Sidneyan notion that art must be both didactic and pleasurable.

${ }^{15}$ Among other failures of perception is Norton's blindness to the attraction he felt toward his own daughter.

${ }^{16}$ Callahan (40) quotes W. E. B. Du Bois as a source of this notion of ambivalence: "The history of the American Negro is the history of this strife,this longing to attain self-conscious manhood, to merge his double self into a better and truer self"' (Du Bois 17).
\end{abstract}

\title{
Works Cited
}

Abrahams, Roger D. Deep Down in the Jungle . . .: Negro Narrative Folklore from the Streets of Philadelphia. Hatboro: Folklore Assoc., 1964.

Alighieri, Dante. The Divine Comedy. Trans. C. H. Sisson. Chicago: Regnery Gateway, 1980.

Baker, Houston. "Utile Dulce and the Literature of the Black American." Singers of Daybreak: Studies in Black American Literature. Washington: Howard UP, 1974. 1-7.

Blake, Susan L. "Ritual and Rationalization: Black Folklore in the Works of Ralph Ellison." Ralph Ellison. Ed. Harold Bloom. New York: Chelsea, 1986. 77-99.

Bruss, Elizabeth. Autobiographical Acts: The Changing Situation of a Literary Genre. Baltimore: Johns Hopkins UP, 1976.

Callahan, John F. "The Historical Frequencies of Ralph Waldo Ellison." Chant of Saints: A Gathering of Afro-American Art, Literature and Scholarship. Ed. Michael S. Harper and Robert B. Stepto. Urbana: U of Illinois P, 1979. 33-53.

Du Bois, W. E. B. The Souls of Black Folk. 1903. New York: Fawcett, 1961.

Eakin, Paul John. Fictions in Autobiography: Studies in the Art of Self-Invention. Princeton: Princeton UP, 1985.

Ellison, Ralph. Invisible Man. ["30th Anniversary Edition" with an Introduction by the author dated November 1981.] New York: Vintage, 1982.

- "On Initiation Rites and Power: Ralph Ellison Speaks Out at West Point." Comparative Literature Spring 1974. Rpt. Going to the Territory. New York: Random, 1986. 39-63.

Shadow and Act. New York: Random, 1964.

Gates, Henry Louis, Jr. "The Blackness of Blackness: A Critique of the Sign and the Signifying Monkey." Black Literature and Literary Theory. Ed. Gates. New York: Methuen, 1984. 285-321.

Howe, Irving. "Black Boys and Native Sons." A Casebook on Ralph Ellison's Invisible Man. Ed. Joseph F. Trimmer. New York: Crowell, 1972. 150-71.

Olney, James. Metaphors of Self: The Meaning of Autobiography. Princeton: Princeton UP, 1972.

Stepto, Robert B. "Literacy and Hibernation in Ralph Ellison's Invisible Man." Ralph Ellison. Ed. Harold Bloom. New York: Chelsea, 1986. 51-77.

Vauthier, Simone. "Not Quite on the Beat: An Academic Interpretation of the Narrative Stances in Ralph Ellison's Invisible Man." Delta (Montpellier, France) no. 18 (1984): 69-88.

Wright, Richard. 'Introduction: How 'Bigger' Was Born." Native Son. 1940. New York: Harper, 1966. vii-xxxiv.

Winther, Per. "The Ending of Ralph Ellison's Invisible Man." CLA Journal 25 (1982): 267-87. 